\title{
Effects of including corn distillers dried grains with solubles in dairy calf feeds
}

\author{
F. X. Suarez-Mena, ${ }^{\star}$ T. M. Hill, $†$ A. J. Heinrichs,${ }^{\star 1}$ H. G. Bateman II,† J. M. Aldrich,† and R. L. Schlotterbeck† \\ *Department of Dairy and Animal Science, The Pennsylvania State University, University Park, 16802 \\ †Nurture Research Center, Provimi North America, Lewisburg, OH 45338
}

\begin{abstract}
A series of 5 trials was conducted to determine the effect of distillers dried grains with solubles (DG) in calf diets. Trial 1 compared 0 or $49 \%$ DG in $18 \%$ crude protein (CP) starters (as-fed basis) fed to calves initially 2 to $3 \mathrm{~d}$ old for $56 \mathrm{~d}$. Digestibility was estimated during d 52 to 56 using chromic oxide. Trial 2 compared 0 or $39 \%$ DG in $16 \%$ CP growers fed to calves from 8 to 12 wk of age from $28 \mathrm{~d}$. Trial 3 compared 0,10 , or $20 \%$ DG in $18 \%$ CP starters fed to calves initially 2 to $3 \mathrm{~d}$ old for $56 \mathrm{~d}$. Trial 4 compared 0 or $20 \%$ DG in $16 \% \mathrm{CP}$ growers fed to calves from 8 to $12 \mathrm{wk}$ of age from $28 \mathrm{~d}$. As DG increased in all diets, acid detergent fiber, neutral detergent fiber, and fat increased and calculated metabolizable energy was similar but not equalized. In trials 1 and 3 , calves $(\mathrm{n}=48 /$ trial $)$ housed in individual pens were fed $26 \% \mathrm{CP}, 17 \%$ fat milk replacer powder and weaned at $28 \mathrm{~d}$. Trials 2 and 4 used calves $(\mathrm{n}=$ $48 /$ trial) housed in group pens (6 calves/pen) that had been weaned for $28 \mathrm{~d}$ before the trials' start. Trial 5 (n $=18$ calves) had the same starter treatments as trial 3 fed in combination with high or low milk replacer intake, with calves killed at $35 \mathrm{~d}$ to determine effects of DG and milk replacer intake on rumen development. In trial 1 , average daily gain (ADG) was $6 \%$ greater and dry matter digestibility was $10 \%$ greater for calves fed $0 \%$ versus $49 \%$ DG. In trial 2 , ADG (9\%), feed efficiency $(10 \%)$, and hip width change $(19 \%)$ were greater for calves fed $0 \%$ versus 39\% DG. Performance measures did not differ among starter treatments in Trials 3 and 5 . In trial 4, ADG (4\%), feed efficiency (5\%), and hip width change (19\%) were greater for calves fed $0 \%$ versus $20 \%$ DG. In trial 5, rumen development was not affected by DG inclusion, but was greater for calves fed milk replacer at 630 versus $940 \mathrm{~g} / \mathrm{d}$, which had greater starter intake. Overall, we conclude that high levels of distillers in calf starters and growers decrease growth
\end{abstract}

Received September 21, 2010.

Accepted February 3, 2011.

${ }^{1}$ Corresponding author: ajh@psu.edu of calves; however, starters with $\leq 20 \%$ DG allow for normal growth rates and rumen development.

Key words: corn distillers grains, digestion, rumen development

\section{INTRODUCTION}

Corn distillers dried grains with solubles (DG) is frequently priced attractively relative to other commodities. It has been used successfully in the diets of growing beef animals to increase ADG and feed efficiency (Klopfenstein et al., 2008). Young calves benefit from starch-containing diets because of their amylase-based intestinal enzyme system and the starch fermentation end products (i.e., VFA) that stimulate development of the rumen epithelium. Unlike corn, a principal ingredient in US calf starters, DG is low in starch and high in fiber considered to be digestible fiber in older ruminants (NRC, 2001).

Limited published research exists relative to feeding DG to young calves. Thomas (2006) reported feed efficiency decreased as DG increased $(0,28$, and $57 \%$ of diets) in pelleted starters replacing soybean meal in calves under 12 wk of age. Rumen papillae length, width, and surface area decreased linearly as DG increased. Rumen mucosal parakeratosis was reported in calves fed the $57 \%$ DG starter but not in calves fed the 0 and 28\% DG starters. In older calves, 13 to $24 \mathrm{wk}$ of age, Larson et al. (2006) reported no performance differences when calves were fed free-choice alfalfa hay and a limit-fed concentrate based on either soybean meal or DG. Research with other low-starch, high-fiber concentrates replacing corn have shown a decrease in feed efficiency, digestion, or ADG (Fiems et al., 1986; Williams et al., 1987; Hill et al., 2008) in calves $<12$ wk of age. However, there is substantial rumen fermentation in calves by 8 wk of age (Quigley et al., 1991; Vazquez-Anon et al., 1993; Holtshausen and Cruywagen, 2000).

The objective of these trials was to evaluate effects of various inclusion rates of DG in calf starters replacing soybean meal and corn on calf ADG, intake, feed efficiency, DM digestion, and rumen development. 
Five trials were conducted in sequential fashion, first evaluating high inclusions of DG in calves $<2$ mo old, measuring digestion and performance and high inclusions of DG in diets of 2- to 3-mo-old calves, measuring performance. Based on the initial results, lower rates of DG were then evaluated in calves $<2$ mo of age and 2 to $3 \mathrm{mo}$ of age. Our hypothesis was that large amounts of DG would decrease performance; however, some unknown lower amount would not. A secondary objective was to evaluate effect of milk replacer intake (thus affecting grain intake) on rumen development.

\section{MATERIALS AND METHODS}

\section{Trial 1}

Starter diets (Poet, Caro, MI), containing either 0 or $49 \%$ DG on an as-fed basis, were randomly assigned to 48 Holstein bull calves (initially 2 to $3 \mathrm{~d}$ old and $43 \pm 2 \mathrm{~kg}$ of BW; 24 calves/treatment) that were maintained in $1.2 \times 2.4-\mathrm{m}$ individual pens bedded with straw within a curtain sidewall barn with no added heat. Diets were formulated to contain similar nutrient concentrations (18\% CP, $0.0025 \%$ decoquinate; Table 1) and manufactured as complete pellets to provide as homogenous a feed as possible. The amount of DG selected was based on providing the entire supplemental $\mathrm{CP}$ required, meeting but not exceeding the $18 \% \mathrm{CP}$ as-fed minimum for the diet. The 0\% DG diet used soybean meal as the sole source of supplemental CP. Calves were fed $26 \% \mathrm{CP}, 17 \%$ fat milk replacer powder (Table 2) at $0.681 \mathrm{~kg}$ as-fed $/ \mathrm{d}$ and weaned at $28 \mathrm{~d}$. Calves were fed milk replacer (MR) halved into a.m. and p.m. feedings for $25 \mathrm{~d}$, followed by only the a.m. feeding (half of the previous MR) on d 26, 27, and 28. The MR was reconstituted at the rate of $134 \mathrm{~g}$ of powder into a volume of $1 \mathrm{~L}$ with warm water. Measurements were continued for another $28 \mathrm{~d}$ for a trial that lasted $56 \mathrm{~d}$. Calves were received at approximately $1100 \mathrm{~h}$ after a 3.5 -h transit $(\mathrm{d}-1)$. Calves were fed MR at the p.m. feeding and the following a.m. feeding. At $1100 \mathrm{~h}$ the day after arrival, calves were weighed (initial BW), blood was sampled from the jugular vein to measure serum protein using an optical refractometer (ATAGO U.S.A., Inc., Bellevue, WA), and calves were randomly assigned to and offered dietary treatments (d 0). Starter diets and water were offered ad libitum.

Starter contained $0.25 \%$ chromic oxide to estimate digestibility. Fecal grab samples were taken from 4 calves/treatment on the last $5 \mathrm{~d}$ of the trial, frozen daily, combined on an equal wet weight basis, and subsampled for analysis. Approximately $110 \%$ of the estimated feeds needed for each treatment were manufactured as single batches. Equal samples of manufactured feeds were collected from every second bag $(22.7 \mathrm{~kg})$ of feed at the time of manufacturing and composited. Composites of feed and feeds were analyzed (AOAC, 2000) for DM (oven method 930.15), CP (Kjeldahl method 988.05), and $\mathrm{Ca}, \mathrm{P}, \mathrm{K}, \mathrm{Mg}$ (dry ashing, acid digestion, analysis by inductively coupled plasma spectroscopy; method 985.01), and Cr (AOAC, 2000; method 993.14) concentrations. Additionally, starter was analyzed for NDF with ash concentration by the procedure of Van Soest et al. (1991) without sodium sulfite or $\alpha$-amylase, and ADF with ash concentration (Robertson and Van Soest, 1981). Measured concentrations of $\mathrm{Cr}$ and other nutrients in feed, feed intake, and $\mathrm{Cr}$ and other nutrient concentrations in feces were used to estimate fecal output and apparent digestibility.

Calves were weighed every $7 \mathrm{~d}$ until the end of the trial (d 56). Dry feed offered and feed refusals were weighed daily. Fecal scores were assigned daily on a 1 to 5 system ( 1 being normal, thick in consistency; 2 being normal, but less thick; 3 being abnormally thin but not watery; 4 being watery; 5 being watery with abnormal coloring) while calves were in individual pens. Hip widths were measured with a caliper and the BCS of calves was measured during the initial (d 0) measurement period and every $14 \mathrm{~d}$ thereafter. A 1 to 5 system using 0.25-unit increments, with 1 being emaciated and 5 being obese, was used for BCS (Wildman et al., 1982). Scores were based on changes around the vertical and transverse processes of the spine as palpated by one experienced technician and ranged from 1.5 to 3.5. During this January through March trial, ambient temperature inside the barn averaged $3^{\circ} \mathrm{C}$ and ranged from -12 to $28^{\circ} \mathrm{C}$, based on hourly measurements.

Calves were cared for in accordance with the Guide for the Care and Use of Agricultural Animals in Agricultural Research and Teaching (FASS, 1999). Calves received an intranasal, tissue-sensitive respiratory disease vaccine (TSV-2, Pfizer, Exton, PA) and subcutaneous injections of vitamins A, D, E (Vital E-A+D, Schering-Plough Animal Health, Union, NJ), and Se (MU-SE, Schering-Plough Animal Health) upon arrival. Calves received an i.m. respiratory disease vaccine (Bovi-Shield Gold 5, Pfizer, Exton, PA) at d 7 and again at $\mathrm{d} 28$. At $\mathrm{d} 14$, they received an i.m. vaccine for types C and D clostridia (UltraChoice 7, Pfizer, Exton, PA). A pasturella vaccine (Presponse HM; Fort Dodge Animal Health, Fort Dodge, IA) was administered i.m. on d 28 and 42. Calves were castrated and dehorned at $36 \mathrm{~d}$ of age. Animals that required medication for sickness were treated per veterinary recommendation and treatments were recorded daily. Scouring was the only sickness observed, and it was diagnosed based on 
Table 1. Ingredient and chemical composition of starter and grower diets evaluating dried distillers grains with solubles (DG) in trials 1 to 5

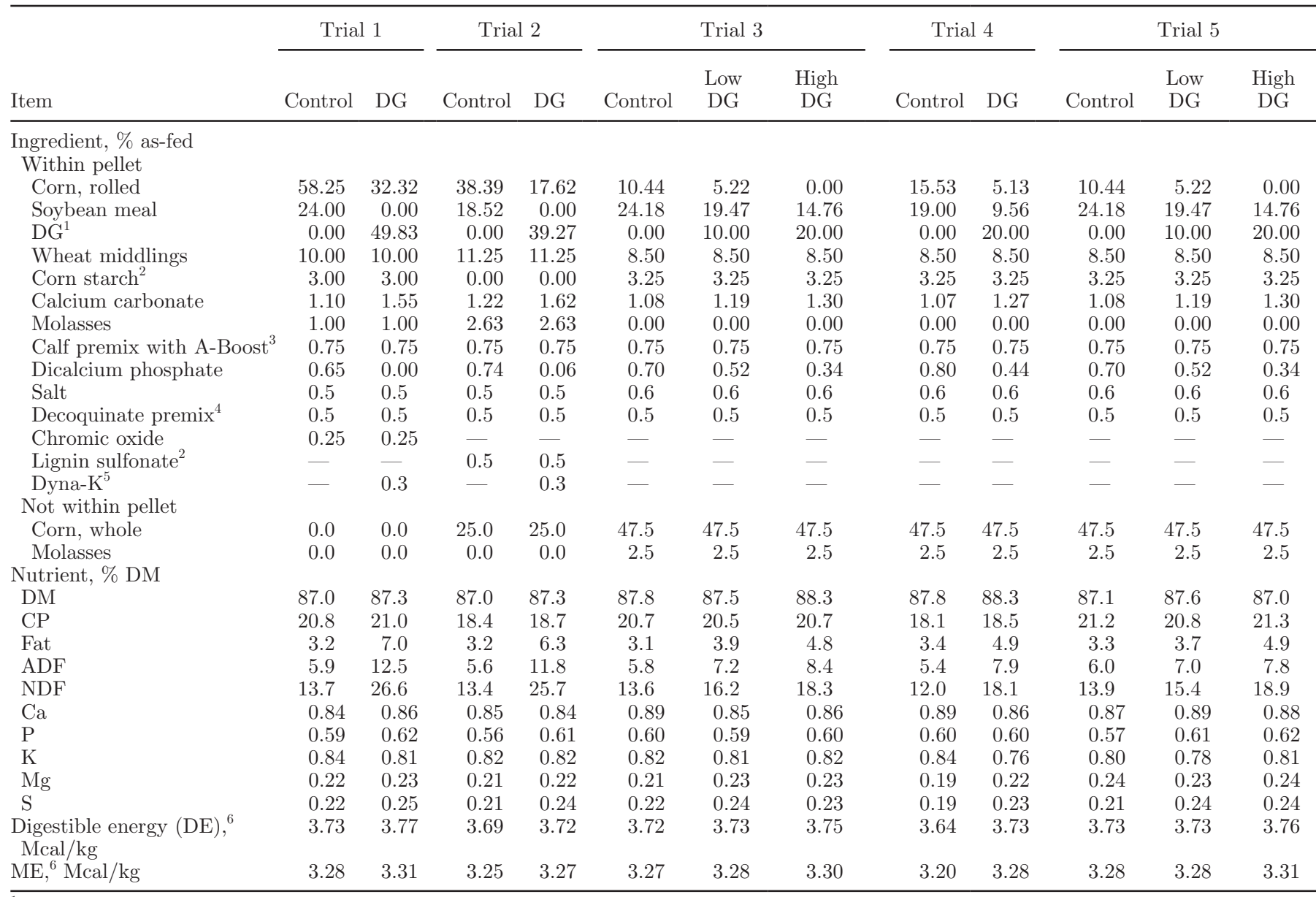

${ }^{1} \mathrm{DG}$ nutrient composition (\% DM): $30.24 \mathrm{CP}, 11.42$ fat, 11.02 ADF, 26.5 NDF, 0.036 Ca, 0.918 P, 1.044 K, 0.43 Mg, 0.61 S, 3.974 Mcal of DE/ $\mathrm{kg}$, and $3.18 \mathrm{Mcal}$ of $\mathrm{ME} / \mathrm{kg}$.

${ }^{2}$ Pellet binder.

${ }^{3}$ Premix provided the following added concentrations (calculated) in the final diets shown: $16 \mathrm{mg}$ of $\mathrm{Cu} / \mathrm{kg}, 1.2 \mathrm{mg}$ of $\mathrm{Co} / \mathrm{kg}, 94 \mathrm{mg}$ of Fe/kg, $1.2 \mathrm{mg}$ of I/ $\mathrm{kg}, 54 \mathrm{mg}$ of $\mathrm{Mn} / \mathrm{kg}, 0.3 \mathrm{mg}$ of Se/kg, $67 \mathrm{mg}$ of $\mathrm{Zn} / \mathrm{kg}, 8.5 \mathrm{kIU}$ of vitamin A/kg, $2.8 \mathrm{kIU}$ of vitamin D/kg, $72 \mathrm{IU}$ of vitamin E/ $\mathrm{kg}$, $27 \mu \mathrm{g}$ of biotin $/ \mathrm{kg}, 6 \mu \mathrm{g}$ of cobalamin $/ \mathrm{kg}, 86 \mu \mathrm{g}$ of folic acid $/ \mathrm{kg}, 3,678 \mu \mathrm{g}$ of niacin $/ \mathrm{kg}, 2,747 \mu \mathrm{g}$ of pantothenic acid/kg, $488 \mu \mathrm{g}$ of pyridoxine/ $\mathrm{kg}, 611 \mu \mathrm{g}$ of riboflavin $/ \mathrm{kg}$, and $611 \mu \mathrm{g}$ of thiamin $/ \mathrm{kg}$; Provimi North America (Brookville, $\mathrm{OH}$ ).

${ }^{4}$ Concentration: $5 \mathrm{~g} / \mathrm{kg}$ (Alpharma Inc., Fort Lee, NJ).

${ }^{5}$ Mosaic USA (Plymouth, MN).

${ }^{6}$ Calculated using NRC (2001) equations.

rectal temperature $>39.5^{\circ} \mathrm{C}$, lack of vitality, and fecal score $>2$ and treated with s.c. ceftiofur sodium (Naxcel; Pharmacia \& Upjohn Co., Kalamazoo, MI).

Data were analyzed using the MIXED procedure in SAS (Version 8, SAS Institute Inc., Cary, NC) as a completely randomized design. Calf within treatment was a random effect used to test the fixed effect of treatment. Day was a repeated measure using an autoregressive type 1 covariance structure within preweaning and postweaning periods. Data reported are least squares means. The experimental unit was calf.

\section{Trial 2}

In Trial 2, 8 pens of Holstein steer calves (4 pens/ treatment; 6 calves/pen; initially $70 \pm 2 \mathrm{~kg}$ and $8 \mathrm{wk}$ old) were randomly assigned to grower diets that contained 0 or $39 \%$ DG (Table 1). The amount of DG was selected based on providing the entire supplemental $\mathrm{CP}$ required, meeting but not exceeding the $16 \% \mathrm{CP}$ as-fed minimum for the diet. The 0\% DG diet used soybean meal as the sole source of supplemental CP. These 2 diets were blended with $5 \%$ chopped grass hay and fed 
Table 2. Nutrient composition (\% DM) of milk replacer powder and hay

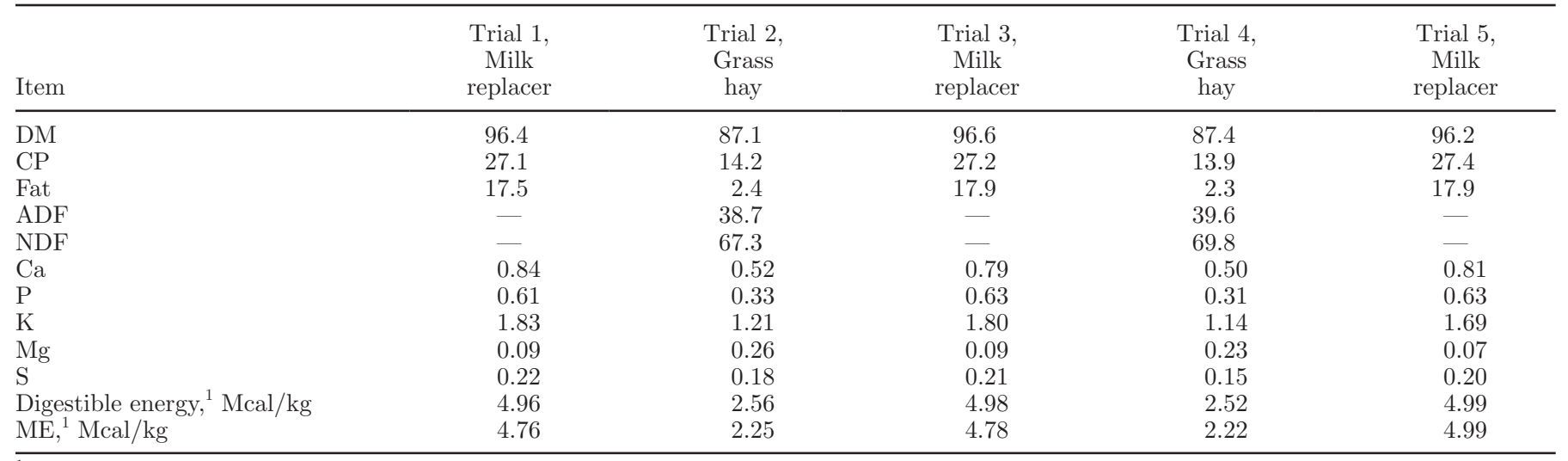

${ }^{1}$ Calculated using NRC (2001) equations.

to calves ad libitum (Table 2). Water was offered free choice via an automated frost-free waterer. Calves were housed in group pens (6 calves/pen) with $5.5 \mathrm{~m}^{2}$ of outside pen space and $0.9 \mathrm{~m}^{2}$ of inside pen space per calf for the 56-d trial. Inside pen space was bedded with straw and had no added heat.

Calves were weighed, hip widths were measured with a caliper, and body condition was scored initially and at the end of the trial (d 0 and 28). Feed offered and refused was weighed daily. Throughout this trial conducted during February and March, ambient temperature averaged $-1^{\circ} \mathrm{C}$ and ranged from -22 to $25^{\circ} \mathrm{C}$ based on hourly measurements.

Approximately $110 \%$ of the diets needed for each treatment were made as 1 batch of feed in advance and samples taken from every third bag $(22.7 \mathrm{~kg})$. Additionally, approximately $120 \%$ of the hay needed was set aside in advance of the trial and 2 samples were taken per bale $(25 \mathrm{~kg})$. Samples were composited and subsampled by treatment and analyzed as described for trial 1.

Trial 2 was analyzed as a completely randomized design using the MIXED procedure of SAS (Version 8, SAS Institute Inc.). Pen was a random effect and treatment was a fixed effect. The experimental unit was pen.

\section{Trial 3}

Starter diets (Poet), containing either 0, 10, or $20 \%$ DG on an as-fed basis were randomly assigned to 48 Holstein bull calves (initially 2 to $3 \mathrm{~d}$ old and $46 \pm 1 \mathrm{~kg}$ of $\mathrm{BW} ; 16$ calves/treatment) that were maintained in $1.2 \times 2.4-\mathrm{m}$ individual pens bedded with straw within a curtain sidewall barn with no added heat. Diets were formulated to contain similar nutrient concentrations (18\% CP, $0.0025 \%$ decoquinate; Table 1) and manufactured as textured diets. The amount of DG was selected to replace a smaller fraction of soybean meal protein based on the results of trial 1 . Other management practices and measurements were the same as in trial 1, with the exception that $\mathrm{Cr}$ was not included in diets and estimates of digestibility were not made. During this trial conducted in April and May, the ambient temperature inside the barn averaged $16^{\circ} \mathrm{C}$ and ranged from 0 to $32^{\circ} \mathrm{C}$, based on hourly measurements.

Data were analyzed using the MIXED procedure in SAS (Version 8, SAS Institute Inc.) as a completely randomized design. Calf within treatment was a random effect used to test the fixed effect of treatment. Day was a repeated measure using an autoregressive type 1 covariance structure within preweaning and postweaning periods. Linear and quadratic polynomial contrasts were used to separate means. Data reported are least squares means. The experimental unit was calf.

\section{Trial 4}

In Trial 4, 8 pens of Holstein steer calves (4 pens/ treatment; 6 calves/pen; initially 8 wk old and $77 \pm 3$ $\mathrm{kg}$ of $\mathrm{BW}$ ) were randomly assigned grower diets that contained 0 or $20 \%$ DG. The amount of DG was selected based on results of trials 1, 2, and 3. The 0\% DG diet used soybean meal as the sole source of supplemental CP. Diets were blended with 5\% chopped grass hay and fed to calves ad libitum with ad libitum water. Calves were housed in group pens (6 calves/pen) with $5.5 \mathrm{~m}^{2}$ of outside pen space and $0.9 \mathrm{~m}^{2}$ of inside pen space per calf for the 56-d trial. Inside pen space was bedded with straw and had no added heat. For this trial conducted during May and June, the ambient temperature averaged $21^{\circ} \mathrm{C}$ and ranged from 5 to $32^{\circ} \mathrm{C}$, based on hourly measurements.

Management practices and measurements were the same as in trial 2. Data were analyzed as a completely 
randomized design using the MIXED procedure of SAS (Version 8, SAS Institute Inc.). Pen was a random effect and treatment was a fixed effect. The experimental unit was pen.

\section{Trial 5}

Protocols for this study were approved by The Pennsylvania State University Institutional Animal Care and Use Committee. Holstein bull calves $(\mathrm{n}=18$; initially 2 to $4 \mathrm{~d}$ old and $46 \pm 3 \mathrm{~kg}$ of BW) were randomly assigned to treatments in a $2 \times 3$ factorial arrangement with 2 levels of MR intake, high (HMR) or low (LMR), and either 0,10 , or $20 \%$ DG (Poet) on an as-fed basis in the starter (same starter treatments as trial 3). Milk replacer (Table 2) was reconstituted at the rate of 134 $\mathrm{g}$ of powder into a volume of $1 \mathrm{~L}$ with warm water, and fed at $0.670 \mathrm{~kg}$ as-fed/d for the LMR treatment (similar to trials 1 and 3). The HMR treatment started at 0.670 $\mathrm{kg}$ as-fed/d with increments of $0.067 \mathrm{~kg}$ as-fed $/ \mathrm{d}$ for 6 $\mathrm{d}$ until reaching $1.072 \mathrm{~kg}$ as-fed/d. Calves were fed MR halved into a.m. and p.m. feedings until d 34. Intake was determined by weighing offered and refused MR. Starter diets (Table 1) were offered ad libitum; refusals were weighed weekly. Water was offered free choice in water bowls. Starter was manufactured and analyzed as in trial 1.

Calves where purchased from a commercial dairy farm and transported for $20 \mathrm{~min}$ to the final housing facility. Upon arrival, calves were weighed and fed $2 \mathrm{~L}$ of electrolytes. Calves were maintained in $2.1 \times 1.6 \mathrm{~m}$ individual pens bedded with wood shavings in a mechanically ventilated, temperature-controlled barn. The day after arrival and weekly at $4 \mathrm{~h}$ post-a.m. feeding, blood was sampled from the jugular vein into evacuated tubes containing EDTA. Plasma total protein concentration was measured using an optical refractometer (ATAGO SPR-T2; Atago Co., Ltd., Tokyo, Japan) and packed cell volume by micro-hematocrit centrifugation $(13,460 \times g$ for $5 \mathrm{~min})$. Health was monitored daily for each calf by evaluating scours, respiration, and general appearance (Lesmeister and Heinrichs, 2004). Animals that required medication for sickness were treated per veterinary recommendation. This trial was conducted during February and March.

At $35 \mathrm{~d}$ of age calves were killed via captive bolt stunning and exsanguination. Reticulo-rumens, omasums, and abomasums were collected, emptied, rinsed with cold water, drained of excess water, dissected, and weighed. Livers were collected, rinsed with cold water, dried with paper towels, and weighed. Rumen sampling and rumen papillae and wall thickness measurements followed Lesmeister et al. (2004) methods, with 2 modifications: 8 papillae were measured per sample (40 per area) and rumen wall thickness was measured twice per sample (10 per area).

Data were analyzed using the MIXED procedure in SAS (Version 9.2, SAS Institute Inc.) as a completely randomized design. Calf within treatment was a random effect used to test the fixed effect of treatment. Linear and quadratic polynomial contrasts were used to separate means. Starter intake was calculated by total starter intake divided by age; ADG was calculated as the difference between initial BW and BW at harvest. Repeated measures using an autoregressive type 1 covariance structure were used for MR intake with day as repeated measure, final blood parameters with week as repeated measure, and rumen development parameters with sub-area as repeated measure. Data reported are least squares means, and the experimental unit was calf. Significance for all studies was determined at $P<$ 0.05 and trends at $P<0.10$.

\section{RESULTS AND DISCUSSION}

Initial calf measurements did not differ and no animals or data were removed from trials 1 to 4 . Plasma protein and packed cell volume initial measurements tended to be higher for the low-milk treatment in trial 5; however, when added as covariates in the model, these were not significant and were not included in the final model. One calf was removed from trial 5 due to circumstances not related to treatments.

As DG increased in all diets, ADF, NDF, and fat increased and calculated ME was similar but not equalized. In trial 1, ADG from d 28 to 56 was $6 \%$ greater (Table 3) and DM digestibility was $10 \%$ greater for calves fed $0 \%$ versus $49 \%$ DG (Table 4 ). In trial 2, ADG (9\%), feed efficiency (10\%), and hip width change (19\%) were greater for calves fed $0 \%$ versus 39\% DG (Table 5). In trial 3, performance measures did not differ among starter treatments (Table 3). Calf ADG were not different in calves fed $0 \%$ versus 10 or $20 \%$ DG in trials 3 (Table 3) and 5 (Table 6). In trial 4, ADG (4\%), feed efficiency ( $5 \%$ ), and hip width change (19\%) were greater for calves fed $0 \%$ versus $20 \%$ DG (Table 5). Starter intake for LMR was $113 \%$ greater and ADG was $20 \%$ lower than for HMR, with no differences for DG inclusion (Trial 5; Table 6). Inclusion of DG in starter did not affect rumen development of 35-d-old calves, but rumen papillae length and width, and weights of reticulo-rumens and omasums of calves on the LMR treatment were greater; liver weight was greater for the HMR treatment (trial 5; Table 6).

No interaction effects were found for MR intake and DG inclusion in trial 5. Greater rumen development at weaning ensures a smoother transition to dry feeds, and calves in the LMR intake group had greater rumen 
Table 3. Performance of calves $<2$ mo of age fed starters with 0 or $49 \%$ dried distillers grains with solubles (DG) in trial 1 and 0,10 , or $20 \%$ DG in trial 3



development than calves on HMR because of a greater starter intake (Table 6). This behavior has been previously reported (Leaver and Yarrow, 1972; Morrison et al., 2009; Hill et al., 2010). Rumen papillae growth is stimulated by the end products of grain fermentation (Harrison et al., 1960). This explains the link between lower grain intakes and lower rumen development. The HMR calves had greater liver weight (Table 6); this observation is consistent with that of Kamiya et al. (2009). Plasma protein was higher for LMR calves, con- sistent with the observations of Morrison et al. (2009). Calf health score was similar across milk replacer and starter treatments in trial 5 .

Thomas (2006) reported feed efficiency decreased as DG increased $(0,28$, and $58 \%$ of diets $)$ replacing soybean meal in pelleted starters in calves from $<1$ wk to 12 wk old. Rumen papillae length, width, and surface area decreased linearly as DG increased. Rumen mucosal parakeratosis was reported in calves fed the $57 \%$ DG starter but not in calves fed the 0 and $28 \%$

Table 4. Intake and apparent total tract digestibility of nutrients in 8 calves fed starter with 0 and $49 \%$ dried distillers grains with solubles (DG) as determined on d 52 to 56 (DM basis)

\begin{tabular}{lcccc}
\hline Item & Control & DG & SEM & $P$-value \\
\hline Calves, $\mathrm{n}$ & 4 & 4 & - & - \\
Intake, g/d & & & & \\
DM & 2,116 & 2,022 & 216 & 0.67 \\
CP & 383 & 370 & 40 & 0.75 \\
Fat & 59 & 123 & 10 & 0.01 \\
Ca & 15.4 & 15.2 & 1.6 & 0.86 \\
P & 10.8 & 10.9 & 1.1 & 0.91 \\
Digestibility, g/g & & & & 0.01 \\
DM & 0.784 & 0.676 & 0.006 & 0.94 \\
CP & 0.641 & 0.639 & 0.078 & 0.12 \\
Fat & 0.685 & 0.822 & 0.072 & 0.15 \\
Ca & 0.183 & 0.300 & 0.084 & 0.31 \\
P & 0.470 & 0.563 & & \\
Digested, g/d & & & 148 & 0.19 \\
DM & 1,583 & 1,365 & 17 & 0.57 \\
CP & 244 & 234 & 11 & 0.01 \\
Fat & 41 & 102 & 0.9 & 0.13 \\
Ca & 2.8 & 4.5 & & 0.35 \\
P & 5.0 & 6.1 & & \\
\hline
\end{tabular}


Table 5. Performance of 2- to 3-mo-old calves fed growers for $28 \mathrm{~d}$ with 0 or $39 \%$ dried distillers grains with solubles (DG) in trial 2 , and 0 or $20 \%$ DG in trial 4

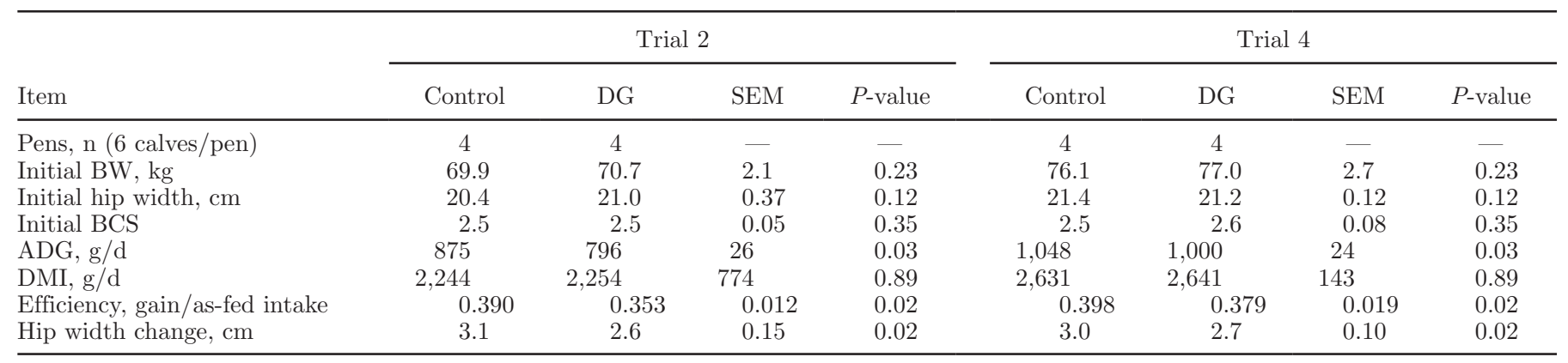

DG starters. Chestnut and Carr (2007) reported that calves $<2$ mo of age fed starters with DG had less ADG and tended to have less ADG than calves fed starters with soybean meal. They had some confounding of starter form and composition. The decrease in calf ADG and feed efficiency observed in trials 1 and 2 were more pronounced than observations by Thomas (2006) and Chestnut and Carr (2007). However, the lack of change in performance in trials 3 and 5 , and moderate decrease in trial 4 was more consistent with the reports of Thomas (2006) and Chestnut and Carr (2007). Other comparisons with DG in young calves were not found in the literature. Larson et al. (2006) reported no performance differences in 13 - to 24 -wk-old calves fed free-choice alfalfa hay and limit-fed concentrate based on either soybean meal or DG.

High levels of fat in calf starter can negatively affect growth and performance of calves, and decrease the palatability of starter, thus intake (Miller et al., 1959; Miller, 1962). In trials 1 and 2, the treatment starter and grower, respectively, had about twice the fat content of the control diets. Greater fat intake of treatment calves in trial 1 may be the cause for the lower DM digestibility (Table 4). Fat can also adversely affect rumen fermentation (NRC, 2001), which may have decreased DM digestibility.

Fiems et al. (1986) reported that replacement of soybean meal with corn gluten feed decreased feed

Table 6. Performance, rumen development measures, digestive organ weights, and blood parameters of calves fed starters with 0 , 10 , or $20 \%$ dried distillers grains with solubles (DG) at high or low milk replacer (MR) intake and harvested at $35 \mathrm{~d}$ of age in trial 5

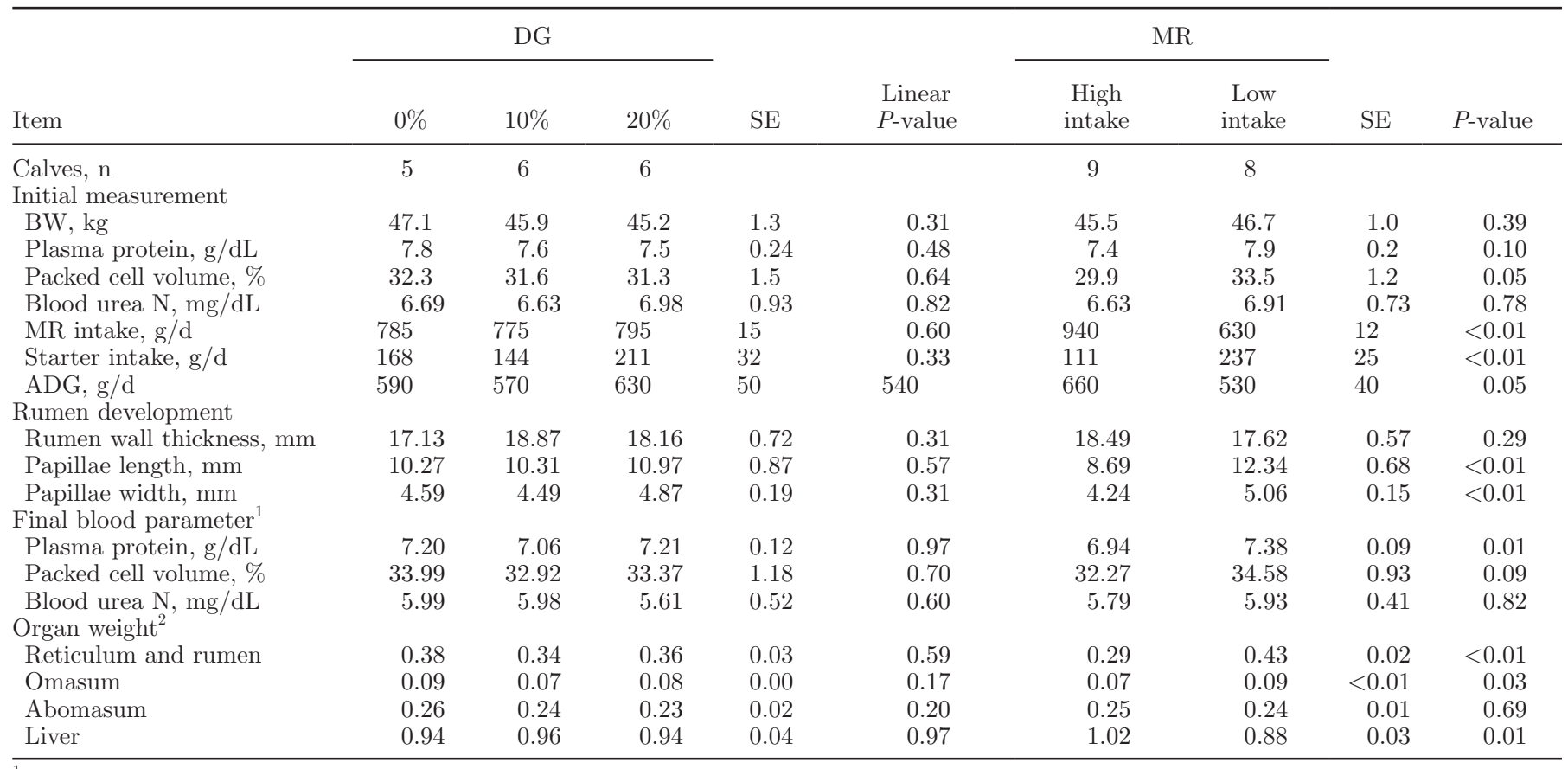

${ }^{1}$ Weekly measurements over the length of the experiment.

${ }^{2}$ Expressed as percentage of BW on harvest day. 
efficiency and increased intake, while not changing ADG. Hill et al. (2008) reported lower ADG and feed efficiency in 2-d to 12-wk-old calves fed starter and grower diets with soyhulls versus corn. Williams et al. (1987) fed calves from 14 to $91 \mathrm{~d}$ old diets with $20 \%$ ground straw and observed similar ADG in calves fed barley or a citrus and beet pulp combination, but feed efficiency was greater when barley was fed. In a similar second study, Williams et al. (1987) fed calves barley or beet pulp (without molasses) and reported DM and $\mathrm{N}$ digestion was lower in calves fed beet pulp. Collectively, these trials (Fiems et al. 1986, Williams et al. 1987, and Hill et al. 2008) suggest that replacement of corn with a more fibrous concentrate will decrease feed efficiency, digestion, or ADG.

Even though ample evidence exists that young calves have substantial rumen fermentation (Quigley et al., 1991; Vazquez-Anon et al., 1993; Holtshausen and Cruywagen, 2000), the amount of fermentation does not appear adequate to equalize ADG between a lowfiber, corn-based diet and diets with concentrates high in fiber like DG, corn gluten feed, citrus pulp, beet pulp, and soy hulls. Additionally, little evidence exists that a digestible fiber source is needed in the diet of a young calf, as suggested by NRC (2001).

\section{CONCLUSIONS}

Including 39 to $49 \%$ DG in the diets of calves $<3$ mo of age decreased ADG by 6 to $10 \%$ and decreased DM digestibility by $10 \%$ in the 7 -wk-old calf. Starters containing up to $20 \%$ DG had no effect on ADG and efficiency in calves $<2$ mo old or on rumen development of 35 -d-old calves. Inclusion of $20 \%$ DG in the diet of 2- to 3-mo-old calves decreased ADG by $4 \%$. High milk intake significantly decreased starter intake, which negatively affected rumen development in 5 -wkold calves. These results support including $<20 \%$ DG in grower diets of calves $<3$ mo old and up to $20 \%$ DG in starters fed to calves $<2$ mo old. Feeding higher rates of MR decreased grain intake and limited rumen development.

\section{REFERENCES}

AOAC. 2000. Official Methods of Analysis. Vol. I. 17th ed. Association of Official Analytical Chemists, Arlington, VA.

Chestnut, A. B., and D. L. Carr. 2007. The performance of calves fed starter feeds containing distillers grains. J. Dairy Sci. 90(Suppl. 1):111 (Abstr.)

FASS. 1999. Guide for the Care and Use of Agricultural Animals in Agricultural Research and Teaching. 1st rev. ed. Federation of Animal Science Societies, Savoy, IL.

Fiems, L. O., V. Boucqué, B. G. Cottyn, and F. X. Buysse. 1986. Cottonseed meal and maize gluten feed versus soybean meal as protein supplements in calf starters. Arch. Anim. Nutr. 36:731-740.
Harrison, H. N., R. G. Warner, E. G. Sander, and J. K. Loosli. 1960 Changes in the tissue and volume of the stomachs of calves following the removal of dry feed or consumption of inert bulk. J. Dairy Sci. 43:1301-1312.

Hill, T. M., H. G. Bateman II, J. M. Aldrich, and R. L. Schlotterbeck. 2008. Effects of feeding different carbohydrate sources and amounts to young calves. J. Dairy Sci. 91:3128-3137.

Hill, T. M., H. G. Bateman, J. M. Aldrich, and R. L. Schlotterbeck. 2010. Effect of milk replacer program on digestion of nutrients in dairy calves. J. Dairy Sci. 93:1105-1115.

Holtshausen, L., and C. W. Cruywagen. 2000. The effect of age on in sacco estimates of rumen dry matter and crude protein degradability in veal calves. S. Afr. J. Anim. Sci. 30:212-219.

Kamiya, M., M. Matsuzaki, H. Orito, Y. Kamiya, Y. N. Nakamura, and E. Tsuneishi. 2009. Effects of feeding level of milk replacer on body growth, plasma metabolite and insulin concentrations, and visceral organ growth of suckling calves. Anim. Sci. J. 80:662-668.

Klopfenstein, T. J., G. E. Erickson, and V. R. Bremer. 2008. Boardinvited review: Use of distillers by-products in the beef cattle feeding industry. J. Anim. Sci. 86:1223-1231.

Larson, R., B. Ziegler, J. Linn, D. Ziegler, and H. Chester-Jones. 2006 Performance of Holstein dairy heifers fed concentrate diets containing dried distillers grains or urea. J. Dairy Sci. 89(Suppl. 1):365 (Abstr.)

Leaver, J. D., and N. H. Yarrow. 1972. Rearing of Dairy Cattle. 2 Weaning calves according to their concentrate intake. Anim. Prod. 14:161-165.

Lesmeister, K. E., and A. J. Heinrichs. 2004. Effects of corn processing on growth characteristics, rumen development, and rumen parameters in neonatal dairy calves. J. Dairy Sci. 87:3439-3450.

Lesmeister, K. E., P. R. Tozer, and A. J. Heinrichs. 2004. Development and analysis of a rumen tissue sampling procedure. J. Dairy Sci. $87: 1336-1344$

Miller, W. J. 1962. Comparison of lard, tallow, butter, and hydrogenated cottonseed oil on starters and of pelleted vs. nonpelleted coastal bermudagrass hay for calves. J. Dairy Sci. 45:759-764.

Miller, W. J., J. L. Carmon, and H. L. Dalton. 1959. Influence of high levels of plant and animal fats in calf starters on growth, feed consumption, and palatability. J. Dairy Sci. 42:153-158.

Morrison, S. J., H. C. F. Wicks, R. J. Fallon, J. Twigge, L. E. R. Dawson, A. R. G. Wylie, and A. F. Carson. 2009. Effects of feeding level and protein content of milk replacer on the performance of dairy herd replacements. Animal 3:1570-1579.

National Research Council. 2001. Nutrient Requirements of Dairy Cattle. 7th rev. ed. Natl. Acad. Sci., Washington, DC.

Quigley, J. D. III, L. A. Caldwell, G. D. Sinks, and R. N. Heitmann. 1991. Changes in blood glucose, nonesterified fatty acids, and ketones in response to weaning and feed intake in young calves. J. Dairy Sci. 74:250-257.

Robertson, J. B., and P. J. Van Soest. 1981. The detergent system of analysis and its application to human foods. Pages $123-158$ in The Analysis of Dietary Fiber in Foods. W. P. T. James and O. Theander, ed. Marcel Dekker Inc., New York, NY

Thomas, M. 2006. Growth, rumen development, and metabolism of Holstein calves fed distillers grains. MS Thesis. South Dakota State Univ., Brookings.

Van Soest, P. J., J. B. Robertson, and B. A. Lewis. 1991. Methods for dietary fiber, neutral detergent fiber, and nonstarch polysaccharides in relation to animal nutrition. J. Dairy Sci. 74:3583-3597.

Vazquez-Anon, M., A. J. Heinrichs, J. M. Aldrich, and G. A. Varga 1993. Effect of post-weaning age on rate of in situ protein disappearance in calves weaned at 5 weeks of age. J. Dairy Sci. $76: 2749-2757$.

Wildman, E. E., G. M. Jones, P. E. Wagner, R. L. Bowman, H. F. Troutt Jr., and T. N. Lesch. 1982. A dairy cow body condition scoring system and its relationship to selected production characteristics. J. Dairy Sci. 65:495-501.

Williams, P. E. V., R. J. Fallon, G. M. Innes, and P. Garthwaite. 1987. Effect on food intake, rumen development and live weight of calves of replacing barley with sugar beet-citrus pulp in a starter diet. Anim. Prod. 44:65-73. 